\section{Condutas em neurologia infantil}

Maria Valeriana Leme de Moura-Ribeiro, Lisiane Seguti Ferreira (Editores)

Um volume $(23 \times 16 \mathrm{~cm})$ com 496 páginas. ISBN: 85-7309781-7. Rio de Janeiro, 2010: Revinter (Rua do Matoso 170, 20270-130 Rio de Janeiro RJ, Brasil / E-mail: livraria@ revinter.com.br)

Nesta edição, as coordenadoras, Professora Maria Valeria Leme de Moura-Ribeiro e Dra. Lisiane Seguti Ferreira, revisaram e atualizaram o livro que traz uma ampla abordagem dos assuntos mais relevantes em Neurologia Infantil de acordo com a visão prática e atualizada de diversos autores.

Este livro expõe, de maneira didática, temas que vão desde o período neonatal e ao longo da primeira década até à adolescência, incluindo aspectos emergenciais e também de caráter predominantemente ambulatorial, assim oferecendo ao leitor uma revisão relativamente rápida, porém profunda, dos diferentes tópicos relativos à Neurologia Infantil.

A leitura é agradável, e os avanços bem como a atualização dos temas essenciais àqueles que atendem crianças com distúrbios neurológicos são de fácil compreensão, o que reflete a enorme experiência das coordenadoras e autores.

É um livro de excelente conteúdo e, em nossa opinião, a sua leitura é fundamental para neurologistas e pediatras.

\section{Erasmo Barbante Casella}

\section{Beyond therapy: biotechnology and the pur- suit of happiness}

Leon R. Kass (Editor)

Um volume $(12 \times 20 \mathrm{~cm}), 373$ páginas. ISBN 1-932594-

05-01. New York, 2006: Dana Press (900 $15^{\text {th }}$ Street, N. W., Washington, D.C., 2005).

As contribuições deste livro envolvem 17 autoridades americanas que discutem o uso atual e futuro das descobertas da biotecnologia, além da terapia (beyond therapy).
Um exemplo simples ilustra a situação: um jogador de basquetebol quer aumentar sua altura em 10 centímetros para concorrer melhor contra os seus adversários no basquetebol. Ele consegue isso com injeções de hormônios da pituitária, o que faz com que aumente a sua altura. Esse procedimento claramente não é feito para tratar uma doença; vai além da terapia. Tal ocorrência deve ser permitida para um jogador profissional? Se sim, devem os seus adversários ser informados dessa situação, e podem eles também fazer a mesma coisa?

Outras questões são bem mais complexas. Provavelmente nos próximos vinte anos a manipulação genética irá ter capacidade de produzir seres humanos com inteligência bem superior à que eles teriam sem tal manipulação. Deverá isso ser permitido? E quem irá tomar a decisão? Os pais de tal indivíduo? Uma comissão governamental? Um instituto científico que irá recrutar cientistas superdotados ou outros grupos? Observa-se que, o ser super inteligente não participa dessa decisão. É possível que ele mais tarde, na sua vida, vá lamentar a sua formação que será diferente de outras pessoas da sua idade ou sexo? Os problemas éticos multiplicam-se com a biotecnologia mais e mais poderosa, que estão "in the pipeline" e provavelmente vão se tornar uma realidade daqui a mais ou menos vinte ou trinta anos.

Uma grande parte do livro trata das consequências de se viver muito mais anos, com boa saúde, devido a técnicas já disponíveis e outras que certamente vão ser uma realidade dentro de dez ou trinta anos. As consequências de viver até 80, 90, 100 ou mais anos de vida, devem produzir problemas sociais e econômicos. As autoridades que deram contribuições para o livro concordam que a hora para resolver estas questões éticas (bioéticas) seria neste momento e não quando eles constituírem a realidade.

Mas tudo já existe. Por exemplo, um dos autores desta análise de livro tem 86 anos de idade, tem boa saúde e clínica em neurologia 50 horas / cada semana. E isso sem qualquer tecnologia especial.

\section{H. Chapman \\ Marta Alves Reis Soares}

